\title{
Highly Pathogenic Avian Influenza H5N1 in Chickens in Upper Egypt
}

\author{
Hatem S. Abd El-Hamid, Hany F. Ellakany, Ahmed R. Elbestawy and Abd Elkader M. Abd \\ Elkader ${ }^{*}$ \\ Poultry and Fish Diseases Department, Faculty of Veterinary Medicine, Damanhur University, \\ Egypt
}

\begin{abstract}
One-year surveillance of HPAI (H5N1) virus infection in different chicken flocks (141 flock) from different Governorates in Upper Egypt was carried out, during the period from January 2015 to January 2016. The detection rate of highly pathogenic avian influenza (HPAI) H5N1 virus was $21.3 \%(30 / 141)$ which was highest during the winter season compared with the other seasons. The investigated flocks suffered from respiratory and nervous signs and cyanosis of the comb and wattles was observed in some birds as well as subcutaneous hemorrhages in shanks. The thirty positive H5N1 samples were tested for the existence of other respiratory viruses. The results were as follows: single $\mathrm{H} 5 \mathrm{~N} 1$ virus infection was only detected in 5 flocks $(16.6 \%)$. The mixed H5N1 with H9N2 in 2 flocks (6.6\%); H5N1with NDV in 12 farms (40\%); H5N1 with IBV in 7 farms $(23.3 \%)$ while H5N1, H9N2 and NDV were detected together in 4 flocks (13.3 $\%$ ). The sequence analysis of the HA gene from five selected $\mathrm{H} 5 \mathrm{~N} 1$ isolates revealed that these strains were clustered with Egyptian classical H5N1 viruses (sub-clade 2.2.1.2) of the Eurasian origin. It is concluded that, the five H5N1 subtype isolates of HPAI are clustered with classical H5N1 viruses to subclade 2.2.1.2 of Eurasian origin. Therefore, vaccination of the backyard chicken as well as chicken farms with suitable homologues vaccine to eliminate HPAI virus from Egypt is recommended.
\end{abstract}

Keywords: Highly Pathogenic Avian Influenza H5N1, Chickens, Upper Egypt.

\section{Introduction}

Avian Influenza (AI) viruses are members in the family Orthomyxoviridae, of the genus influenza virus type $\mathrm{A}$. The genome of AI viruses is composed of single stranded RNA with eight gene segments encoding at least ten viral proteins [1]. Based on the haemagglutinin (HA) and neuraminidase (NA), the two-main surface transmembrane glycoproteins, there are at least $18 \mathrm{HA}$ and probably $10 \mathrm{NA}$ subtypes [1]. According to their pathogenicity in chickens, AIV $_{\mathrm{s}}$ which cause asymptomatic infection are recognized as low pathogenic AIV (LPAIV). Meanwhile those AIV causing high mortalities are recognized as highly pathogenic AIV (HPAIV).

In Egypt, in February 2006, severe outbreaks of HPAIV H5N1 emerged in several Governorates and were associated with drastic mortality up to $100 \%$ in infected chickens [2]. The Egyptian strains belonged to subclade 2.2 of the H5N1 virus of Eurasian origin, which is also circulating in the Middle East region. Genetic and antigenic analysis of the circulating field viruses in vaccinated flocks revealed subtype antigenic variation and antigenic drift of the virus in comparison to vaccine strains [3-9].

These mutations allowed the virus to evade the receptor of host immune responses after vaccination [10]. Studies have reported that stable lineages of $\mathrm{H} 5 \mathrm{~N} 1$ viruses are found in vaccinated chickens and humans in Egypt [11]. Two different H5N1 groups of viruses are currently co- circulating in Egypt referred to as classic strains 2.2.1 which is usually isolated from backyard birds (rarely from vaccinated small commercial farms) and humans and variant strains 2.2.1.1 and 2.2.1.2 subclades, isolated from vaccinated and backyard birds, respectively $[12,13]$

In order to recognize the spread of newly emerging influenza variants, continuous surveillance and phylogenetic analysis of the circulating HPAIV H5N1 are necessary [14]. This study aimed to investigate the occurrence of HPAIV H5N1 in commercial chicken flocks in Upper Egypt and determination of genotypic characters of $\mathrm{H} 5$ gene.

\footnotetext{
*Corresponding author email: (abdelkadermohammed37@yahoo.com), Poultry and Fish Diseases 376 Department, Faculty of Veterinary Medicine, Damanhur University, Egypt.
} 


\section{Materials and Methods}

\section{Samples}

Tracheal, cloacal swabs $(n=282)$ and specimens from internal organs $(n=141)$ including (liver, spleen, lung and trachea) prepared as pooled samples, were collected from diseased and freshly dead birds. These specimens represented 141 chicken flocks located in 6 different Governorates in Upper Egypt including Assiut $(\mathrm{n}=87)$, El-Minia $(n=32)$, Sohag $(n=14)$, Quena $(n=3)$, Aswan $(n=3)$ and Elwady Elgadid $(n=2)$.

\section{Virus isolation}

The tissue samples were homogenized and centrifuged at $3000 \mathrm{rpm}$ for $15 \mathrm{~min}$ and the supernatant was collected. The collected swabs and homogenized fluid were mixed with antibiotic solution and inoculated aseptically into 9-11 day old embryonated chicken eggs (free from antibodies against $\mathrm{H} 5 \mathrm{~N} 1$ ) via allantoic sac (AS) route using $0.1 \mathrm{~mL} / \mathrm{egg}$. The inoculated eggs were incubated at $37^{\circ} \mathrm{C}$ and candled daily for 7 days and the allantoic fluids from dead embryos were collected.

Haemagglutination (HA) test was performed and if there was no HA activity, another second passage was done before identifying the specimen as negative [15].

\section{Detection of viral RNA using rRT-PCR}

All HA positive isolates were further identified using Real Time Reverse Transcription Polymerase Chain Reaction (rRT-PCR) with specific primers and probes for AI subtype H5 [16]. The sequences of the primers and probe are listed in Table (1). Extraction of Viral RNA was carried by Thermo Scientific GeneJET Viral RNA Purification Kit according to the manufacturers' instructions.

Table 1: Sequences of primers and probes for detection of AI, ND and IB viruses in chickens in Upper Egypt

\begin{tabular}{lll}
\hline Target gene & Primer & 'sequence (5'-3') \\
\hline H5 (rRT-PCR) & H5LH1 & 5'-ACA TAT GAC TAC CCA CAR TAT TCA G-3' \\
& H5RH1 & 5' AGA CCA GCT AYC ATG ATT GC 3' \\
& H5PRO (Probe) & 5' 'FAM-TCW ACA GTG GCG AGT TCC CTA GCA TAMRA \\
H9 & 3' \\
NDV & H9- & 5'-CTY CAC ACA GAR CAC AAT GG-3' \\
IB & ND-f & 5'-GTC ACA CP GTT GTTGTR TC-3' \\
& ND-R & 5'-TGG AGC CAA ACC GCG CAC CTG CGG-3' \\
& XCE3 & 5'-GAG GAT GTT GGC AGC AT-3' \\
& BCEI & 5'-CAGATTGCTTACAACCACC -3' \\
H5 (RT-PCR) & DCEI & 5'-AGTAGTTTTGTGTATAAACCA-3' \\
& MCEI & 5'- TTCCAATTATATCAAACCAGC-3' \\
& H5- kho-1 & 5'- AATACTACTTTTACGTTACAC-3' \\
& H5- kho-3 & 5'-CCT CCA GAR TAT GCM TAY AAAATT GTC-3' \\
\hline
\end{tabular}

The thermo scientific verso 1- step qRTPCR kit plus Rox vial was used. A total volume of $25 \mu \mathrm{L}$ containing nuclease free water $(3.75 \mu \mathrm{L}), 2 \mathrm{X} 1$ - step PCR ready mix $(12.5 \mu \mathrm{L})$, RT- enhancer $(1.25 \mu \mathrm{L})$, forward primer $(1 \mu \mathrm{L})$, reverse primer $(1 \mu \mathrm{L})$, Verso enzyme mix $(0.25 \mu \mathrm{L})$, probe $(0.25 \mu \mathrm{L})$, extracted RNA $(5 \mu \mathrm{L})$. Thermal cycling consisted of $30 \mathrm{~min}$ at $50^{\circ} \mathrm{C}, 15 \mathrm{~min}$ at $95^{\circ} \mathrm{C}$; then 40 cycles of $10 \mathrm{sec}$ at $95^{\circ} \mathrm{C}, 30 \mathrm{sec}$ at $54^{\circ} \mathrm{C}$, and $10 \mathrm{sec}$ at $72^{\circ} \mathrm{C}$.

\section{Detection of coinfection using RT-PCR}

All positive samples with H5 subtype using rRT-PCR were re-tested for the existence of co-infection with H9 subtype [17], NDV [18] and IBV [19] using Reverse Transcription (RT- PCR) (Table 1).

Viral RNA was extracted from all allantoic fluids using Gene JET Viral DNA and RNA purification kit (Thermo scientific, USA) Cat. No. Ko821. The procedure was performed according to the manufacturer's instruction. Amplification reaction was carried out using Verso one step RT-PCR ready-Mix (Cat. No 
AB- 1454/LD/A) (Thermoscientific, Germany). Reaction mix of RT- PCR: A total volume of $25 \mu \mathrm{L}$ containing $12.5 \mu \mathrm{L}$ RT-PCR Master mix, $1 \mu \mathrm{L}$ of forward primer and $1 \mu \mathrm{L}$ of the reverse primer, $0.5 \mu \mathrm{L}$ of RT enzyme mix, $1 \mu \mathrm{L}$ of RT enhancer, $5 \mu \mathrm{L}$ of template RNA with $4 \mu \mathrm{L}$ of RNase-free water. Thermal cycling consisted of $30 \mathrm{~min}$ at $50^{\circ} \mathrm{C}, 15 \mathrm{~min}$ at $95^{\circ} \mathrm{C}$; then 35 cycles of $1 \mathrm{~min}$ at $94^{\circ} \mathrm{C}, 1 \mathrm{~min}$ at $53^{\circ} \mathrm{C}$, and $1 \mathrm{~min}$ at $72^{\circ} \mathrm{C}$. The reaction was performed in a Stratagene MX3005P RT-PCR machine. For visualization of the amplified products, $2 \%$ agarose solution was prepared in Tris Acetate EDTA (TAE) and $5 \mu \mathrm{L}$ of Ethidium Bromide was added after heating. Ladder DNA $(5 \mu \mathrm{L})$ was added in the $1^{\text {st }}$ lane then $5 \mu \mathrm{L}$ of each sample were added in each lane and the gel was visualized after 40 min of electrophoresis by UV trans-illuminator.

\section{Sequencing of 5 selected H5 isolates}

The HA gene of H5 subtypes was amplified using conventional RT-PCR [20] with specific primers (Table 1). The reaction conditions were performed with a first step of reverse transcription at $50^{\circ} \mathrm{C}$ for $30 \mathrm{~min}$ (one cycle) followed by one cycle of initial denaturation at $94^{\circ} \mathrm{C}$ for $5 \mathrm{~min}$. The amplification cycles consisted of 35 cycles of denaturation at $94^{\circ} \mathrm{C}$ for $30 \mathrm{sec}$, annealing at $56^{\circ} \mathrm{C}$ for $45 \mathrm{sec}$ and extension at $72^{\circ} \mathrm{C}$ for $45 \mathrm{sec}$ followed by 1 cycle of final extension at $72^{\circ} \mathrm{C}$ for $10 \mathrm{~min}$. The amplified products were visualized as previously described. Extraction and purification of the amplicons was performed using QIAquick PCR Product Extraction kit (Qiagen, Valencia CA). The purified products were sequenced with Big dye terminator v 3.1 cycle sequencing kit (Perkin-Elmer/Applied Biosystems, Foster City, CA Cat. number 4336817).

\section{Phylogenetic analysis}

The truncated nucleotide sequences obtained from PCR products were aligned with other HA gene sequences available in GenBank by the ClustalW method, using the MegAlign module of DNAStar software (Lasergene version 7.2; DNASTAR, Madison, WI, USA). The phylogenetic tree was generated using the neighbor-joining method in MEGA version 5 (www.megasoftware.net). The tree topology was evaluated by 1000 bootstrap analyses.

\section{Results}

Specimens from 141 commercial chicken flocks were collected from diseased and freshly dead birds suffering from high mortality, respiratory and nervous signs, cyanosis of comb and wattles as well as subcutaneous hemorrhages in the shank (Figures 1.1 and 1.2) from January 2015 till January 2016. 

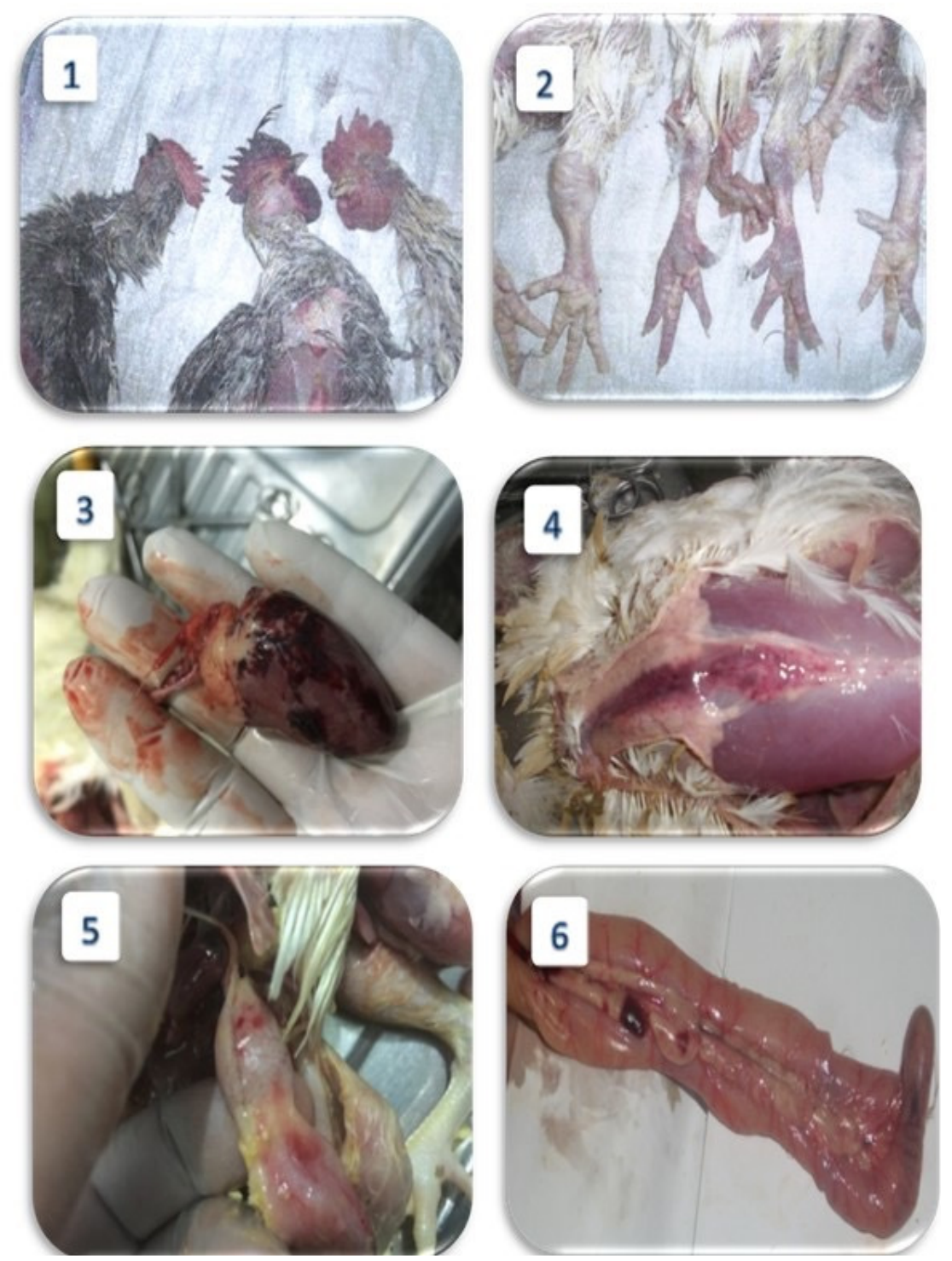

Figure 1: Clinical findings of naturally infected Chicken with HPAI of the H5N1 subtype: 1: Native breed breeders showing cyanosis of comb and wattles; 2: Broiler chicken showing hemorrhages of the shank; 3: Chicken displaying petechial hemorrhages in the myocardium; 4: Chicken, Presenting with abundant serofibrinous subcutaneous edema and hemorrhages in sternal region.;5: Chicken showing petechial haemorrhages on the serosal surface of the proventriculus and 6: Chicken exhibiting hemorrhagic pancreatitis.

All chicken flocks (141) had mortality rate of $10-25 \%$ at last 3 days before sampling, the dead birds showed gross lesions of myocardium hemorrhages (Figure 1.3), sternal edema (Figure 1.4), proventriculus outer serosal surface hemorrhages (Figure 1.5), and pancreatitis (Figure 1.6).

\section{Detection of H5N1 virus in chicken flocks in} Upper Egypt

Seventy-one samples exerted positive HA activity of the inoculated allantoic fluid. Thirty samples were positive for H5 subtype of AIV using rRT-PCR, the detailed data are presented in Table (2).

The thirty positive samples (30) for subtype H5 were selected for further tested via using RT-PCR against AI H9, NDV and IBV to detect the co-infection in positive samples. The results revealed the existence of $\mathrm{H} 5$ and NDV in 12 samples, H5with H9 in 2 samples, $\mathrm{H} 5$ and IBV in 7 samples meanwhile H5, H9 and NDV were detected in 4 samples and only 
5 samples were positive for H5 single infection.

There was a high incidence of HPAIV subtype $\mathrm{H}_{5} \mathrm{~N}_{1}$ during winter season $(76.7 \%)$ then gradually decreased during the rest of the year.

Sequencing for HA gene for the selected isolates

Partial hemagglutinin (HA) gene sequencing (segment 4) was done for five selected isolates which have single infection with HPAI (H5N1) representing Assiut (3), Elmenia (1) and Elwady Elgaded (1) Governorates was conducted in order to perform genetic characterization of the investigated isolates. The isolates were taken from non-vaccinated flocks, single infection was confirmed by RT-PCR to exclude mixed infection.

Table 2: PCR results of H5N1 virus infection in chicken flocks of upper Egypt Governorates

\begin{tabular}{lllll}
\hline \multicolumn{1}{r}{ Governorate } & No. of tested flock & No. of + ve HA & No. of + ve $\mathbf{H}_{\mathbf{5}}$ & \% of +ve 30 flocks \\
\hline Assiut & 87 & 40 & 17 & $56.6 \%$ \\
Elmenia & 32 & 18 & 7 & $23.4 \%$ \\
Sohage & 14 & 9 & 2 & $6.6 \%$ \\
Quena & 3 & 1 & 1 & $3.4 \%$ \\
Aswan & 3 & 1 & 1 & $3.4 \%$ \\
Elwady Elgaded & 2 & 2 & 2 & $6.6 \%$ \\
The Total & 141 & 71 & 30 & $21.3 \%$ of $+\mathrm{ve}\left(\mathrm{H}_{5}\right)$ \\
\hline
\end{tabular}

\section{Phylogenetic analysis}

The obtained partial sequences of HA gene of H5 subtype-AI viruses were compared with other strains from Asia and Europe available from Gene Bank. The data revealed that all the examined strains belonged to subclade 2.2.1.2 of the H5N1 virus of Eurasian origin, which is also circulating in the Middle East region and was introduced into Africa since early 200 


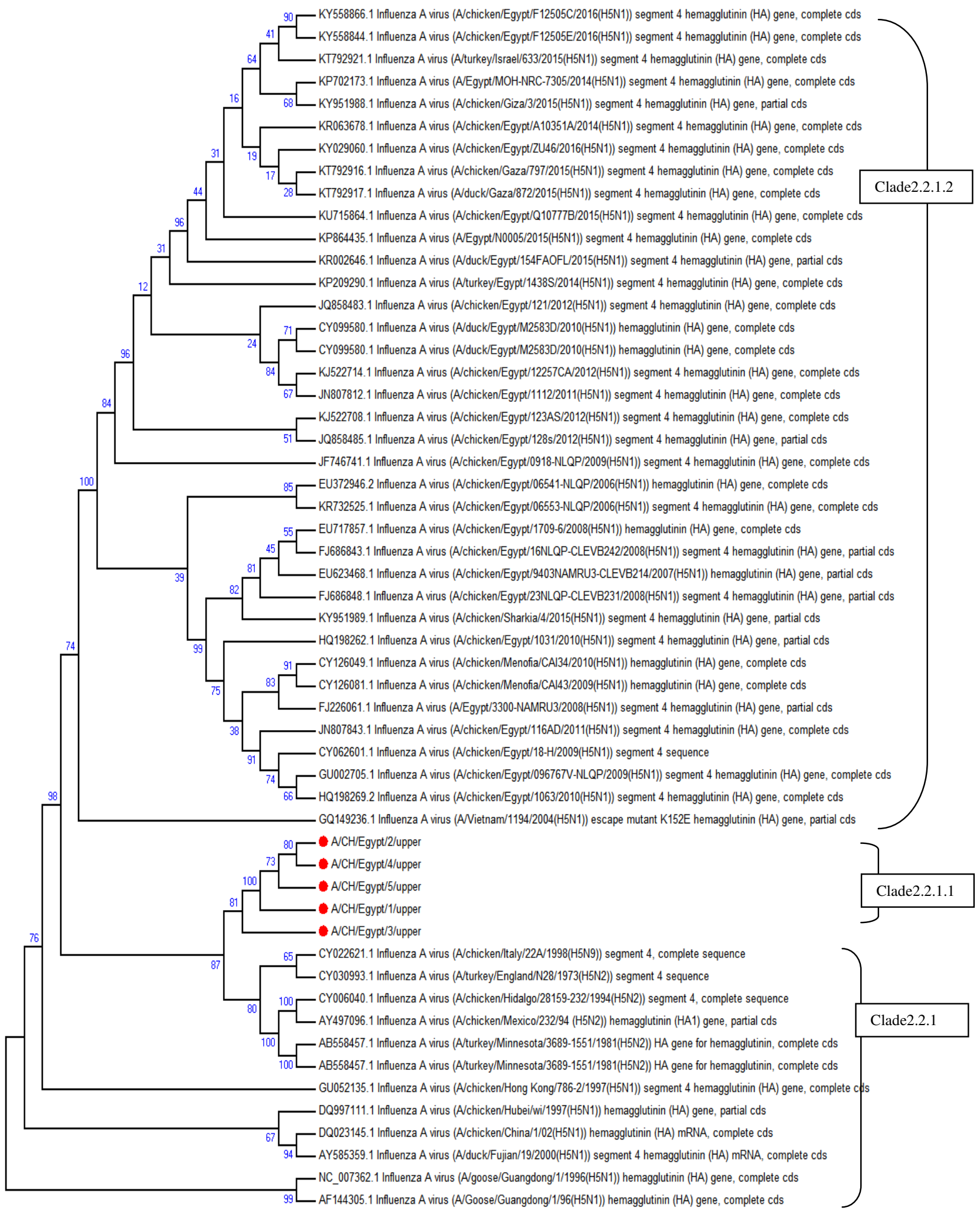

Figure 2: Phylogenetic analysis of HA gene truncated nucleotide sequences of avian influenza virus (AIV) isolated from chicken flocks, upper Egypt Governorates, showing the genetic relationship between representative HPAI (H5N1) virus in the phylogenetic tree and the five studied isolates in the period of 2016 for HA gene segment (4) the five isolates is marked with red circle. The phylogenetic tree was generated using the neighbor-joining method in MEGA version 5 (www.megasoftware.net). 


\section{Discussion}

Poultry infection with type A influenza virus has been recognized since the late $19^{\text {th }}$ century causing mainly sporadic but serious outbreaks of the disease. In 1997, HPAIV $\mathrm{H} 5 \mathrm{Nl}$ containing a group of genes originated from wild aquatic birds was able to replicate causing severe mortalities in gallinaceous birds in Hong Kong [21]. Following culling of all live poultry across Hong Kong, the virus was successfully eradicated; however, in 2003, re-emergence of $\mathrm{A} / \mathrm{H} 5 \mathrm{Nl}$ in domestic and wild birds occurred in Qinghai Lake, China [22-24].

Insufficient economic conditions and poultry infrastructure in Egypt facilitated the entrance and spread of the first of $\mathrm{A} / \mathrm{H} 5 \mathrm{Nl}$ across poultry production sectors and marketing chains resulting in the endemicity of the disease [11]. More than 30 million birds were culled and over one billion US \$ losses in poultry industry have been estimated following the first introduction of infection in 2006 [25].

This study aimed to assess the detection rate of HPAIV/H5N1 in Upper Egypt through detection of AIV in chicken flocks of H5N1 viruses isolated from commercial poultry farms. The data revealed that 71 flocks out of 141 tested chicken flocks in Upper Egypt Governorates were HA positive $(71 \%)$. All these samples were tested by rRT-PCR against subtype $\mathrm{H}_{5}$, and 30 flocks were positive with the percentage of $21.3 \%$ and this percentage was higher than that recorded by Awad et al, [26] who reported H5N1 in $12 \%$ of chicken flocks during late 2013 and 2015 in Alexandria.

This high incidence in Upper Egypt occurred in winter season (16.1) and decreased during the rest of the year, because low temperature and winds in winter increase the viability of the virus. This result coincides with WHO/OIE/FAO H5N1 Evolution Working Group [27] who declared that H5N1 became endemic in Egypt resulting in severe losses in poultry industry mainly in winter season. The percentage of positive H5N1 subtype HPAI samples from chicken farms from Upper Egypt during 2016 is $21.3 \%$ is higher than $12 \%$ recorded in the same year in chicken farms in Alexandria [27].
Partial hemagglutinin (HA) gene (segment 4) sequencing for 5 isolates of $\mathrm{AI} H 5 \mathrm{~N} 1$ were selected to identify the genetic characterization of these isolates. The obtained data revealed that the 5 HPAIV H5N1 isolates were located at one group of Egyptian viruses and their sequences belong to highly diverse clade 2.2.1.2 viruses and this indicated the predominance of this clade. From 2006 till 2014 the subclade 2.2.1.1 of H5N1 subtype of HPAI was dominant in the previously recorded isolates, but in the last two it disappeared due to the vaccination pressure in the chicken farms, however the subclade 2.2.1.2 is the mostly viruses appear in isolation which originated from backyards [27]. In Egypt, continuous vaccination and/or continuous transmission of the virus among the same species and other species explain the recent increased antigenic variation among H5 viruses [28].

\section{Conclusion}

It is concluded that, the five H5N1 subtype isolates of HPAI are clustered with classical $\mathrm{H} 5 \mathrm{~N} 1$ viruses to subclade 2.2.1.2 of Eurasian origin. Vaccination of the backyard chicken as well as chicken farm with suitable homologues vaccine to eliminate HPAI virus from Egypt is recommended.

\section{Conflict of interest}

The authors declare no conflict of interest.

\section{References}

[1] Tong. S., Li,Y. and Rivailler.P. (2012): A distinct lineage of influenza A virus from bats. Proceeding of National Academic Science USA, 109:4269-427.

[2] Aly, M. M., Hassan, M. K. and Arafa, A. (2006): Emergence of highly pathogenic $\mathrm{H} 5 \mathrm{~N} 1$ avian influenza virus in poultry in Egypt. First record of 2006 outbreaks. J. Egy. Vet. Med. Assoc., 66(2): 263-276.

[3] Hafez, M. H., Arafa,A., Abdelwhab,E.M., Selim,A., Khoulosy,S.G., Hassan,M.K., and Aly,M.M. (2010): Avian influenza $\mathrm{H} 5 \mathrm{~N} 1$ virus infections in vaccinated commercial and backyard poultry in Egypt. Poult. Sci. (89):1609-1613

[4] Abdel-Moneim, A.S., Afifi, M.A., El-Kady M.F. (2011a): Genetic drift evolution 
under vaccination pressure among $\mathrm{H} 5 \mathrm{~N} 1$ Egyptian isolates. Virology Journal; 8:283;

[5] Abdel-Moneim A.S., Shehab G.M., AbuElsaad A.A. (2011b). Molecular evolution of the six internal genes of H5N1 influenza A virus. Arch Virol 2011; 156:1257

[6] Abdelwhab, E.M. and Hafez, H.M. (2011): An overview of the epidemic of highly pathogenic $\mathrm{H} 5 \mathrm{~N} 1$ avian influenza virus in Egypt: epidemiology and control challenges. Epidemiol Infect; 139:647-657.

[7] Grund, C., Abdelwhab, E.M., Arafa, A.S., Ziller, M., Hassan, M.K., Aly, M.M., Hafez, H.M., Harder, T.C., Beer, M. (2011): Highly pathogenic avian influenza virus $\mathrm{H} 5 \mathrm{~N} 1$ from Egypt escapes vaccineinduced immunity but confers clinical protection against a heterologous clade 2.2.1 Egyptian isolate. Vaccine, 29:556773.

[8] Rauw, F., Palya, V., Van Borm, S., Welby, S., Tatar-Kis, T., Gardin, Y., Dorsey, K.M., Aly, M.M., Hassan, M.K., and Soliman, M.A. (2011): Further evidence of antigenic drift and protective efficacy afforded by a recombinant HVT-H5 vaccine against challenge with two antigeni-cally divergent Egyptian clade 2.2.1 HPAI H5N1 strains. Vaccine; 29:2590-600.

[9] Abdelwhab, E.M., Grund, C., Aly., M.M., Beer, M., Harder., .M.H ,Hafez and ,.C.T immunity maternal of infuence $:\left(b^{r} \cdot \mid r\right)$ of susceptibility and efficacy vaccine on highly Egyptian against chicks old day one .vet $1 \mathrm{~N}^{\circ} \mathrm{H}$ influenza avian nicpathoge $r \cdot-1 T, 100$.Microbiol

[10] Cattoli, G., Fusaro, A., Monne, I., Coven, F., Joannis, T., El-Hamid, H.S., Hussein, A.A., Cornelius, C., Amarin, N.M.,and Mancin, M. (2011): Evidence for differing evolu-tionary dynamics of $\mathrm{A} / \mathrm{H} 5 \mathrm{~N} 1$ viruses among countries applying or not applying avian influenza vaccination in poultry. Vaccine; 29: 9368-9375.

[11] Abdelwhab, E.M., Grund, C., Aly, M.M., Beer, M., Harder, ,Hafez and,.C.T dose Multiple :(r.1) .M.H heter with vaccinationologous $\mathrm{H} 5 \mathrm{~N} 2$ vaccine: immune response and protection against variant clade 2.2.1 highly pathogenic in $1 \mathrm{NoH}$ influenza ianav .chickens breeder broiler Vaccine ; 29:6219-6225.

[12] Abdelwhab, E.M., Arafa, A.S., Stech, J., Grund, C., Stech, O., GraeberGerberding, M., Beer, M., Hassan, M.K., Aly, M.M., and Harder. T.C. (2012a): Diversifying evolution of highly pathogenic $\mathrm{H} 5 \mathrm{~N} 1$ avian influenza virus in Egypt from 2006 to 2011. Virus Genes 2012; 45:14-23.

[13] World Health Organization, WHO (2012): Cumulative number of confirmed human cases for avian influenza A (H5N1) reported to WHO.

[14] Velijkovic, V., Velijkovic, N.,Muller, C.P., Mu"ller, S.,Glisic,S., Perovic, V.,Ko"hler,H.;(2009):Characterization of conserved properties of hemoagglutinin of H5N1and human influenza viruses: possible consequences for therapy and infection control. BioMed Central (BMC) Structural Biology, 9: 21-31.

[15] OIE, (2015): Avian influenza. Available at:

http://www.oie.int/fileadmin/Home/fr/He alth_standards/tahm/ Chapter 2.03.04 AI.pdf

[16] Slomka, M.J., Coward,V.J., Bank, S.J., Londt, B.Z., Brown, I.H., Voermans, J., Koch, Handberg, K.J., Jorgensen, P.H., Cherbonnel Pansart, M., Jestin,V., Cattoli,G., Capua,I. , Ejdersund,A., Thoren, P., and Czifra,G. (2007): Identification of sensitive and specific avian influenza PCR methods through blind ring trials in the European Union. Avian Dis., 51,227-234

[17] Mosleh, N., Dadras, H., and Mohammadi, A.; (2009): Evaluation of H9N2 avian influenza virus dissemination in various organs of experimentally infected broiler chickens using RT-PCR. Iranian J. Vet. Res., 10: $12-20$.

[18] Mase, M., Imai, K., Sanada, Y., Sanada, N., Yuasa, N., Imada, T., Tsukamoto, K., and Yamaguchi, S.; (2002): Phylogenetic 
analysis of Newcastle disease virus genotypes isolated in Japan. J. of Clinical Microbiol, 40:3826-3830.

[19] Adzhar, A., Gough, R.E., Haydon, D., Shaw, K., Britton, P. and Cavanagh, D. (1997): Molecular analysis of the 793/B serotype of infectious bronchitis virus in Great Britain. Avian Pathol., 26: 625640.

[20] Spackman, E.; Senne, D.A.; Myers, T.J.; Bulaga, L.L.; Garber, L.P.; Perdue, M.L.; Lohman, K.; Daum, L.T. and Suarez, D.L. (2002): Development of a real-time reverse transcriptase PCR assay for type A influenza virus and the avian $\mathrm{H} 5$ and H7 haemagglutinin subtypes. J. Clin. Microbiol. 40: 3256-3260.

[21] Suarez, D.L., Perdue, M.L., Cox, N., Rowe, T., Bender, C., Huang, J. and Swayne, D.E. (1998): Comparisons of highly virulent H5N1 influenza A viruses isolated from humans and chickens from Hong Kong. J. Virol., 72: 6678- 6688.

[22] Chen, H., Smith,G,J,D., Zhang,S.Y., Qin,K., Wang,J., Li,K,S., Webster,R.G., Peiris,J.S.M., and Guan,Y. (2005): H5N1 virus outbreak in migratory waterfowl: a worrying development could help to spread this dangerous virus beyond its stronghold in Southeast Asia. Nature (London) 436:191- 192.

[23] Guan, Y., Poon, L.L., Cheung, C.Y., Ellis,T.M., Lim, W., Lipatov, A.S., Chan, K.H., Sturm-Ramirez, K.M., Cheung, C.L., Y.H. Leung, Y.H., Yuen, K.Y., Webster, R.G. and Peiris, J.S.
(2004): H5N1 influenza: a protean pandemic threat. Proceedings of the National Academy of Sciences U. S. A. 101:8156-8161.

[24] Salzberg,S.L.,Kingsford,C.,Cattoli,G.,Sp iro, D.J., Janies,D.A., Aly,M.M., Brown, I.H., Couacy Hyman,E., DeMia,G.M., Dung, D.H., Guercio,A., Joannis,T., Ali, A.S.M., Osmani, A., Padalino,I., Saad, M.D., Saiv, V., Sengamalay, N.A., Yingst,S., Zaborsky, J., Zorman Rojs,O., Ghedin, E., and Capua.I. (2007): Genome analysis linking recent European and African influenza (H5N1) viruses. Emerging Infectious Diseases 13 (5): 713-718.

[25] Meleigy, M.; (2007): Egypt battles with avian influenza. Lancet 370:553- 554.

[26] Awad,A.M., Ali,A.B., Abd-El-Hamid, H.S, El-Naggar,A.L., Sediek,M.E., N.A., El-Shall, N. A.and El-Samahy,H.S. (2016): Epidmiological studies on H5N1 and H9N2 Avian Influenza viruses during late 2013 and 2015 in Alex. J. Vet. Sci. 51 (2) 7th. Sci. Conf.

[27] WHO/OIE/FAO H5N1 Evolution Working Group (2012): Continued evolution of highly pathogenic avian influenza A (H5N1): updated nomenclature. Influenza Other Respiratory Viruses.;6:1-5.

[28] Lee, C.W.; Senne, D.A. and Suarez, D.L. (2004): Effect of vaccine use in the evolution of Mexican lineage $\mathrm{H} 5 \mathrm{~N} 2$ avian influenza virus. J. Virol. 78:83728381. 


\section{الملخص العربي}

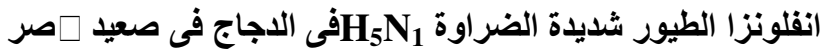

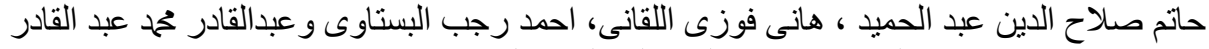

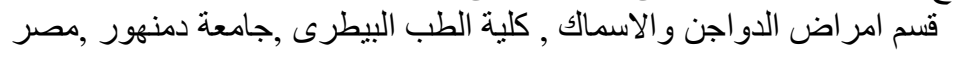

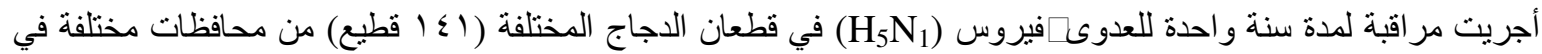

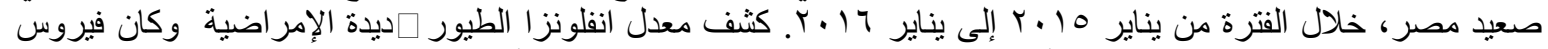

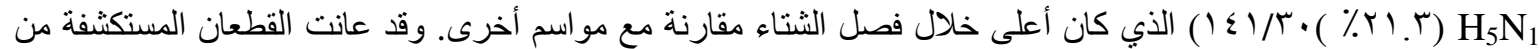

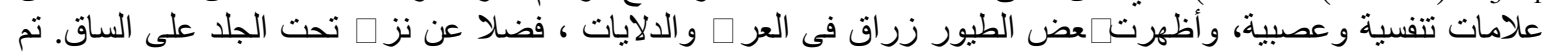

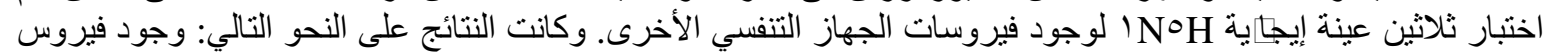
الانفلونزا من النوع (H)

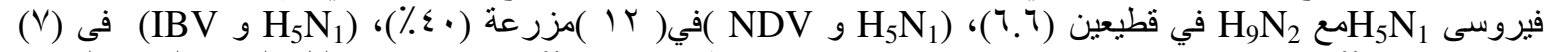

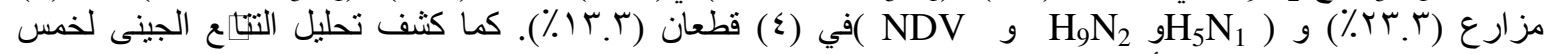

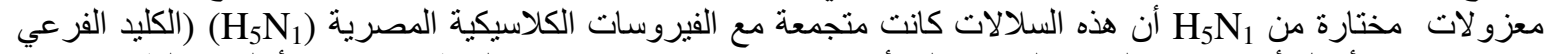

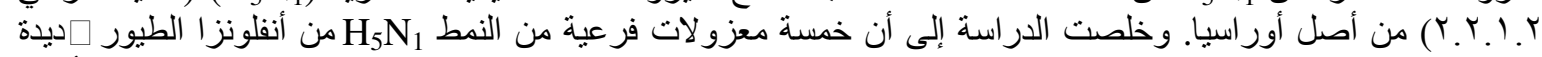

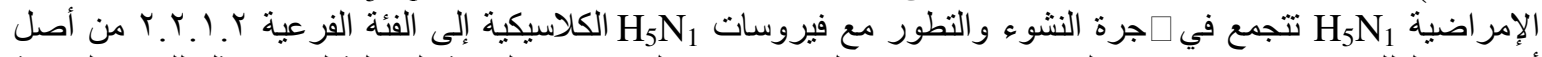

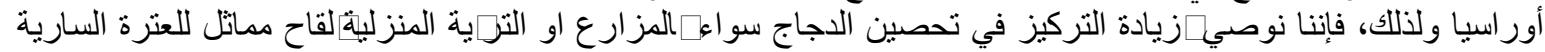
وذللك للنخلص على فيروس فئا نوصب 